\title{
Analysis of allergenic pollen data, focusing on a pollen load threshold statement
}

\author{
Laura Šukienė (D) - Ingrida Šaulienė (1) • Rūta Dubakienè • Odilija Rudzevičienè (i) • \\ Gintautas Daunys (D)
}

Received: 23 June 2020/ Accepted: 7 September 2021 / Published online: 29 September 2021

(C) The Author(s) 2021

\begin{abstract}
Airborne allergenic pollen affects a significant part of the population and the information on pollen load is a valuable tool for public health prevention. The messages should be provided in a form easily understandable for the population. The study provides new insight for the categorisation of pollen load by defining thresholds solely from aerobiological data. Using the long-term airborne pollen data of Corylus, Alnus, Betula, Poaceae, and Artemisia have been evaluated the regionality of pollen concentrations in Lithuania. SPIn and peak values of the main pollen season highlighted as regionality indicators.
\end{abstract}

L. Šukienè $(\bowtie) \cdot$ I. Šaulienè · R. Dubakienè ·

O. Rudzevičienè · G. Daunys

Institute of Regional Development, Šiauliai Academy,

Vilnius University, P. Višinskio st. 25, 76351 Šiauliai,

Lithuania

e-mail: laura.sukiene@sa.vu.lt

I. Šauliene

e-mail: ingrida.sauliene@sa.vu.lt

R. Dubakienè

e-mail: ruta.dubakiene@mf.vu.lt

O. Rudzevičienè

e-mail: odilija.rudzeviciene@santa.lt

G. Daunys

e-mail: gintautas.daunys@sa.vu.lt

O. Rudzevičienè

Clinic of Children's Diseases, Institute of Clinical

Medicine, Faculty of Medicine, Vilnius University,

Santariškiụ st. 7, 08406 Vilnius, Lithuania
The largest differences between stations were found in the cases of Corylus and Artemisia.

The principle enabling a group of pollen concentrations into levels has been analysed based on retrospective aerobiological data of five pollen types. Thresholds were determined by employing the lowest peak value of the pollen season and applying the $25 \%$ principle for selected pollen types. The results were verified by performing associations of defined thresholds with retrospective morbidity data of allergic rhinitis and allergic asthma in Lithuania. Determined pollen thresholds can be used in epidemiological studies requiring associations with pollen concentration. Thresholds could also complement air quality information by integrating pollen load data into public messages or contribute to the development of mHealth systems.

Keywords Pollen load threshold · Pollen peak value Allergic rhinitis Allergic asthma .

Aerobiology

\section{Introduction}

A significant part of the population is affected by pollen-induced allergic rhinitis and allergic asthma (Biedermann et al., 2019; Brożek et al., 2017; Damialis et al., 2019; Valiulis et al., 2019), leading to a decline in the quality of work and leisure for 
individuals (Bastl et al., 2019; Cebrino et al., 2017) and negatively affecting the economy (Belhassen et al., 2017). Air quality, environmental conditions during the plant vegetation season (Bruffaerts et al., 2018), or pollen load due to the long-range pollen transport (Skjøth et al., 2007; Smith et al., 2008; Sofiev et al., 2013) may influence the health of sensitive individuals. It is not possible to eliminate the environmental factors, but pollen impact can be at least partially controlled.

There are about 900 airborne pollen monitoring stations in the world (Buters et al., 2018) with a range of observational data from several years to several decades. Pollen dispersal peculiarities are assessed not only according to pollen abundance parameters (Bogawski et al., 2019; García-Mozo, 2017; Werchan et al., 2017) but also by including the significance of environmental factors for pollen behaviour in the air (Camacho et al., 2020; Oduber et al., 2019; Rahman et al., 2019; Ritenberga et al., 2018; Sauliene et al., 2019). Information about airborne pollen concentration is valuable for various activities, from information to organizers of outdoor events such as the Olympic Games or festivals (Bonini et al., 2015; Katelaris et al., 2000; Lahiri et al., 2010; Stagelund et al., 2019) to individual daily planning.

Information on pollen load levels is more acceptable to the public than reports on pollen concentrations. From a public health standpoint, it is important to know what pollen load can sensitize and what level of concentration in the air can cause allergic reactions. Biogeographical differences and climate define the characteristics of plant distribution, abundance, and peculiarities of local pollen. Pollen concentration, defined as a level or threshold that might impact on an individual's well-being is the subject of scientific discussions often related to circumstances of particular country. Studies in France (Thibaudon, 2003), Poland (Rapiejko et al., 2007), Italy (Marchetti et al., 2017), Germany (Jochner et al., 2015), Finland (Jantunen et al., 2012; Rantio-Lehtimäki et al., 1991) and in other countries (de Weger et al., 2013) specified levels of pollen thresholds and apply them for various purposes. The classification of allergenic pollen load into low, moderate, high, and very high levels is widely used. Levels are determined using different methods, but, in most cases, the associations between allergy symptoms and the characteristics of the pollen season are followed.
There has been considerable progress in the provision of pollen information, and allergists and pollensensitive individuals are now able to access information on the progress of the pollen load continuously and at significant speed. Breakthroughs in technology have resulted in mobile apps becoming available, offering concentrations of allergenic pollen, and relating an individual's health condition to a pollen forecast (Pasyfo, Pollen, Météo Pollen,) or real-time pollen data (Tesendic et al., 2020). Along with the development of the mobile technologies for health (mHealth) concept and the growing need to manage the risks of allergic rhinitis and allergic asthma, aerobiological information together with air quality is becoming one of the preventive tools (Bastl et al., 2019; Matricardi et al., 2020; Pfaar et al., 2017, 2019; Valiulis et al., 2019).

Motivation to improve the usefulness of aerobiological messages and the sufficient quantity of longterm data on airborne allergenic pollen encouraged us to perform this study. Research questions aimed for this study: (1) to propose a method for determining pollen load thresholds solely on pollen monitoring data; (2) to determine thresholds of pollen load evaluating long-term pollen data; (3) to verify the thresholds with Lithuanian retrospective data on morbidity of allergic rhinitis and allergic asthma. Morbidity data of the Lithuanian population were analysed only for the comparison of different pollen load thresholds. It was not aimed to make conclusions about the health effects of pollen.

\section{Material and methods}

\subsection{Study area}

Airborne pollen data and morbidity data for the study were collected in Lithuania. The country is located within the middle-latitude climate zone, with the Baltic coastal climate region being close to Western Europe's climate (LHMS, 2020). In Lithuania, the average temperature in July is around $17^{\circ} \mathrm{C}$ and in January, around $-4{ }^{\circ} \mathrm{C}$. The period of positive temperature (when the average daily temperature is above $0{ }^{\circ} \mathrm{C}$ ) in the East of the country is about 53 days shorter than in the West at the seaside (242 and 295 days, respectively). A $6{ }^{\circ} \mathrm{C}$ isotherm surrounds the cooler highland of Samogitia (Bukantis, 2008). 
Precipitation occurs in all seasons (a $670 \mathrm{~mm}$ average), being more regular between April and October when the weather is warmer (Bukantis et al., 2015).

The country's area is $65300 \mathrm{~km}^{2}$ (Lithuania Statistics, 2020). The vegetation belongs to the hemiboreal area with the temperate zone represented in southern Lithuania (Jõgiste et al., 2017). According to State Forest Service (2019), the total forest land area covers $33.6 \%$ of the country's territory and coniferous stands (mostly Scots pine (Pinus sylvestris) and Norway spruce (Picea abies)) prevail, covering $55.6 \%$ of the forest area. Birch (Betula) stands cover the largest area among deciduous trees and reached $22.1 \%$. Alder (Alnus) covers $13.4 \%$ of the forest area, showing a tendency for an increased area of black alder (Alnus glutinosa), but a decrease in the area of grey alder (Alnus incana).

\subsection{Pollen data}

In the country, three aerobiological stations are equipped to represent the climatic and vegetative regions. The study was performed on airborne pollen data of the plants that are most important from the allergenic standpoint in Lithuania: Betulaceae (analysing Corylus, Alnus, and Betula separately) and Poaceae families and Artemisia genus. These five pollen types comprise approximately $12 \%$ of observed airborne pollen types. The pollen load of selected plants varies from 55 to $62 \%$ of the main pollen load, depending on the observation site. Three locations (Fig. 1) were chosen for pollen monitoring with a 7- day Hirst-type volumetric spore trap (Hirst, 1952).

This device sucks pollen at a speed of $10 \mathrm{l} / \mathrm{min}$, which corresponds to human breathing during rest. Pollen was identified under a microscope in the laboratory manually, using the method of scanning 12 transverse lines (12.27\% of slide). The analysis of samples was performed according to Galán et al. (2014). The amount of pollen detected in the samples is expressed as the number of pollen grains per $\mathrm{m}^{3}$ of air per day.

All available airborne pollen data of Lithuania were analysed in this study. It covers the period 2005-2019. Due to technical malfunction during the sample collection and to ensure the quality of the research results, part of the aerobiological monitoring data was not included in this study. The central criterion for the data set before including them in the research was: no data gaps in the main pollen season. Accordingly, out of 15 seasons, 7 of Corylus and Alnus seasons, 1 Betula and 2 Poaceae and Artemisia seasons were excluded from the analysis.

The analysis of pollen dynamics was performed by evaluating the following characteristics: the beginning and end of the main pollen season (expressed in days from the beginning of the year, DOY), the Seasonal Pollen Integral (SPIn), and the pollen peak value during the season. The $95 \%$ method was used to calculate the mean pollen season (Goldberg et al., 1988). It is considered that the beginning of the pollen season is the day on which the concentration of airborne pollen reaches $2.5 \%$ of the annual pollen integral. Respectively, the end of the pollen season is the date on which pollen concentration reaches $97.5 \%$ of annual pollen integral. The SPIn is calculated by summing the average daily concentration over the year (Galán et al., 2017).

\subsection{Defining the pollen thresholds}

We first identified the peak value of the main pollen season for each observation year. The lowest peak value of the analysed period was chosen as the reference point and divided using the $25 \%$ principle, i.e., the range from zero to this peak value was divided into quarters. Values within the lowest quarter are defined as low, within the second quarter $(25-50 \%$ of the peak value) moderate, within the third quarter $(50-75 \%)$ as high, and within the highest quarter (75-100\%) as very high (Fig. 2).

The scheme demonstrated in Fig. 2 indicates the classification of the pollen concentration into parts. It reflects "low", "moderate", "high", and "very high" levels of the threshold. In order to validate how determined thresholds are close to those adopted in the practice of other geographically nearest countries (Finland and Poland), the thresholds published in scientific publications were used (Table 1). Pollen load thresholds defined by researchers in Finland (de Weger et al., 2013; Jantunen et al., 2012; RantioLehtimäki et al., 1991) and Poland (de Weger et al., 2013; Rapiejko et al., 2007) based on the methodology where pollen concentrations are associated with the health of pollen-sensitive individuals. Consequently, the current study used three groups of pollen thresholds covering results from (1) Finland; (2) Poland and (3) Lithuania. Abbreviations for groups of pollen 


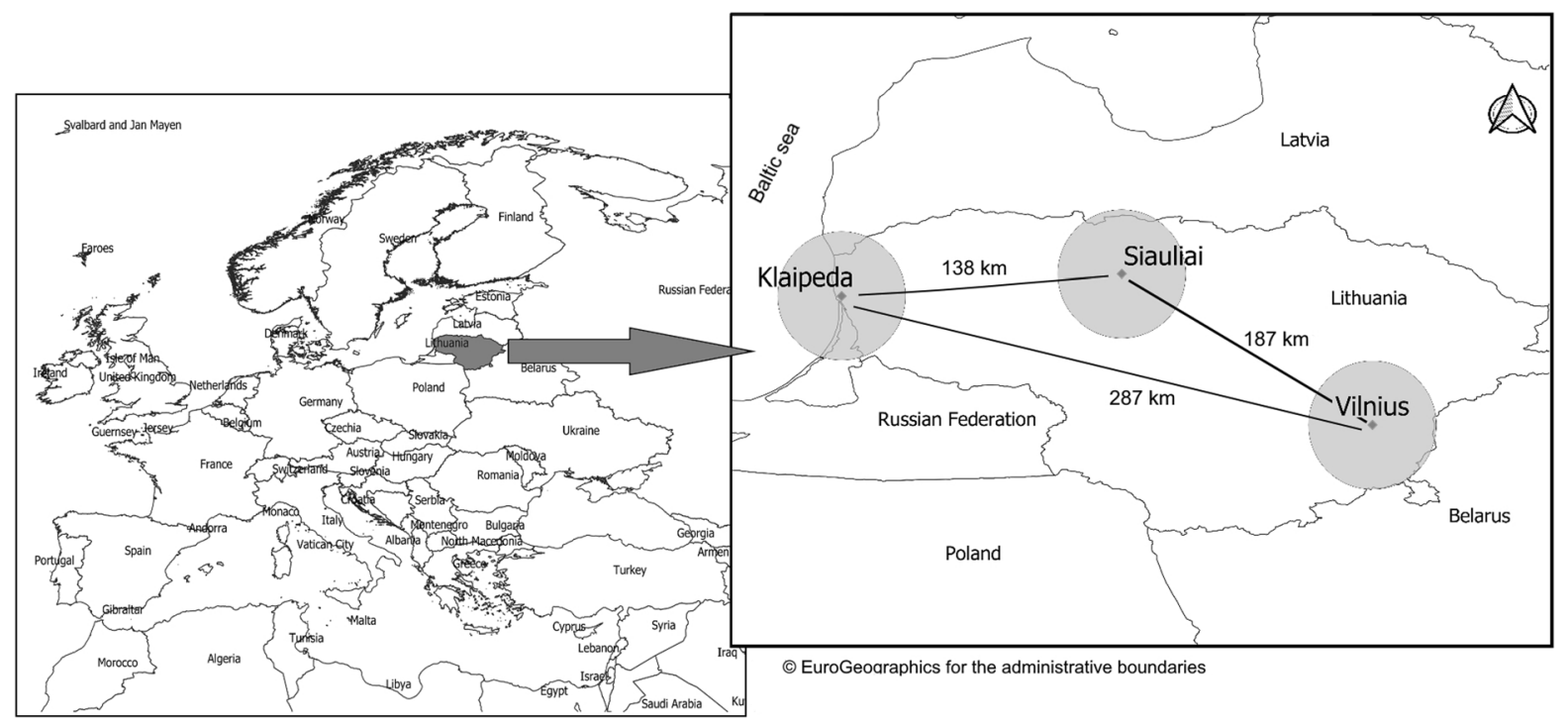

Fig. 1 Airborne pollen sampling sites in Lithuania are marked in dots. Grey circle indicates the region of residents' morbidity data. QGIS 3.6.0 Noosa is used to produce the maps

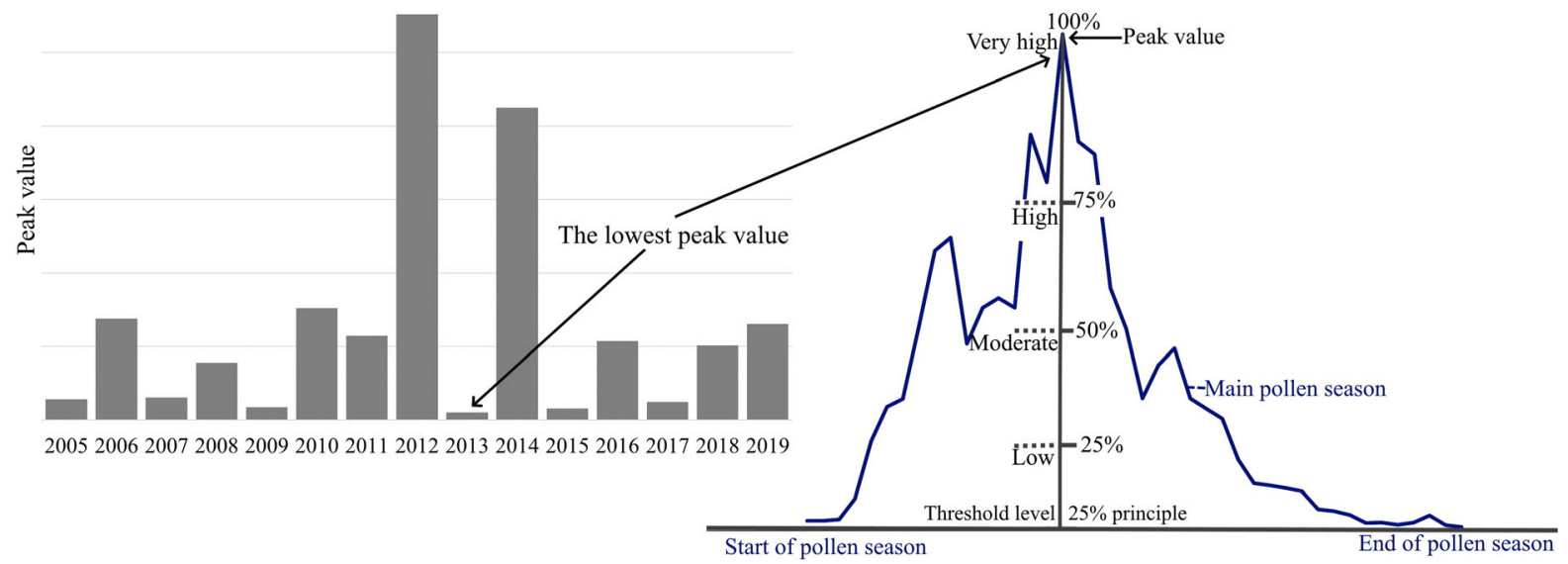

Fig. 2 Scheme for pollen threshold determination from airborne pollen data using the $25 \%$ principle. The lowest annual peak value within a series of years is selected and the range from

thresholds used in the text and tables: (1) TR_FIN (thresholds according to de Weger et al., 2013; Jantunen et al., 2012; Rantio-Lehtimäki et al., 1991), (2) TR_POL (thresholds according to de Weger et al., 2013; Rapiejko et al., 2007) and (3) TR_LIT (thresholds are determined according to pollen data from Lithuanian aerobiological stations, using the $25 \%$ principle for the lowest pollen peak.). zero to this peak value is divided into quarters, which are denoted as low, moderate, high, and very high levels, respectively

\subsection{Morbidity data of allergic rhinitis and allergic asthma}

Depersonalized data on Lithuanian residents' morbidity of pollen-induced allergic rhinitis and allergic asthma were provided by the Institute of Hygiene (responsible for official morbidity statistics). Only data that covers the period of 2011-2018 was available for study. The average numbers of morbidity of allergic rhinitis and allergic asthma individuals registered per year are presented in Table 2. To carry out 
Table 1 A study of applicability of thresholds used for presentation of pollen concentration

\begin{tabular}{|c|c|c|c|c|c|c|c|}
\hline \multirow[t]{2}{*}{$\begin{array}{l}\text { Threshold } \\
\text { according to }\end{array}$} & \multirow[t]{2}{*}{$\begin{array}{l}\text { Abbreviation of } \\
\text { threshold group }\end{array}$} & \multirow[t]{2}{*}{$\begin{array}{l}\text { Threshold } \\
\text { level }\end{array}$} & \multicolumn{5}{|c|}{$\begin{array}{l}\text { Threshold values (pollen } / \mathrm{m}^{3} \text { ) according to pollen } \\
\text { types }\end{array}$} \\
\hline & & & Corylus & Alnus & Betula & Poaceae & Artemisia \\
\hline \multirow{4}{*}{$\begin{array}{l}\text { Rantio-Lehtimäki et al., } \\
\text { (1991); @Jantunen et al., (2012); } \\
\text { de Weger et al., (2013) }\end{array}$} & \multirow[t]{4}{*}{ TR_FIN } & Low & \multicolumn{2}{|l|}{$<10$} & \multicolumn{3}{|c|}{$<10$} \\
\hline & & Moderate & \multicolumn{2}{|l|}{$10-100$} & \multicolumn{3}{|c|}{$10-30$} \\
\hline & & High & \multicolumn{2}{|l|}{$100-1000$} & \multicolumn{3}{|c|}{$>30$} \\
\hline & & Very high & \multicolumn{2}{|l|}{$>1000$} & \multicolumn{3}{|c|}{ n.a } \\
\hline \multirow{4}{*}{$\begin{array}{l}\text { Rapiejko et al., (2007); } \\
\text { de Weger et al., (2013) }\end{array}$} & \multirow[t]{4}{*}{ TR_POL } & Low & $<35$ & $<45$ & $<20$ & $<20$ & $<30$ \\
\hline & & Moderate & $35-80$ & $45-85$ & $20-75$ & $20-50$ & $30-55$ \\
\hline & & High & $80-150$ & $85-95$ & $75-90$ & $50-65$ & $55-70$ \\
\hline & & Very high & $>150$ & $>95$ & $>90$ & $>65$ & $>70$ \\
\hline \multirow{13}{*}{$\begin{array}{l}\text { The lowest peak value }(2005-2019) \\
\text { applying the } 25 \% \text { principle }\end{array}$} & \multirow[t]{13}{*}{ TR_LIT } & Klaipeda & & & & & \\
\hline & & Low & $\leq 1$ & $<63$ & $<78$ & $<11$ & $<10$ \\
\hline & & Moderate & $2-3$ & $63-127$ & $78-156$ & $11-22$ & $10-21$ \\
\hline & & High & $4-5$ & $127-190$ & $156-234$ & $22-33$ & $21-31$ \\
\hline & & $\begin{array}{l}\text { Very high } \\
\text { Siauliai }\end{array}$ & $>5$ & $>190$ & $>234$ & $>33$ & $>31$ \\
\hline & & Low & $<7$ & $<35$ & $<51$ & $<12$ & $<15$ \\
\hline & & Moderate & $7-13$ & $35-71$ & $51-102$ & $12-24$ & $15-29$ \\
\hline & & High & $13-20$ & 71-106 & $102-153$ & $24-36$ & $29-44$ \\
\hline & & $\begin{array}{l}\text { Very high } \\
\text { Vilnius }\end{array}$ & $>20$ & $>106$ & $>153$ & $>36$ & $>44$ \\
\hline & & Low & $<11$ & $<69$ & $<87$ & $<11$ & $<22$ \\
\hline & & Moderate & $11-23$ & 69-139 & $87-174$ & $11-23$ & $22-45$ \\
\hline & & High & $23-34$ & 139-208 & $174-261$ & $23-34$ & $45-67$ \\
\hline & & Very high & $>34$ & $>208$ & $>261$ & $>34$ & $>67$ \\
\hline
\end{tabular}

$T R \_F I N$ : thresholds used in Finland, TR_POL: thresholds used in Poland, TR_LIT: thresholds used in Lithuania. n.a. - the threshold is not determined, not applicable

this research, we used three morbidity data representative regions (Klaipeda, Siauliai, and Vilnius). The region corresponded to the territory covered by aerobiological data and included morbidity data from $\mathrm{a} \sim 50 \mathrm{~km}$ radius from the pollen trap (Fig. 1). Morbidity data are summarised for each region. Due to the geographical peculiarities of the territory, the population of the study areas is different (Table 2).

Official morbidity statistics are used for two purposes. First, in order to reveal the coincidence between morbidity and pollen amount, we compared the data. SPIn, peak value, and morbidity data ranked in descending order with respect to the maximum value from the period 2011-2018. The second objective was to verify the pollen load thresholds with retrospective health data. With this purpose, were tested three groups of pollen thresholds covering results from (1) Finland, (2) Poland, and (3) Lithuania. The performed statistical analysis enabled to evaluate the links between the retrospective data of allergic rhinitis and allergic asthma cases in Lithuania (2011-2018) and pollen load thresholds. This study does not analyse how pollen concentrations alter patients' health status and we did not aim to show the risk of allergies possibly due to airborne pollen.

\subsection{Statistical analysis}

Statistical data analysis was performed using $\mathrm{R}$ version 3.5.0 ( $\mathrm{R}$ Core Team, 2018) and R Studio version 1.1.447 (RStudio Team, 2016). The ShapiroWilk test was used to test the normal distribution of 
Table 2 Population size (Statistics Lithuania, 2020) and morbidity in allergies and asthma in three different regions of Lithuania (2011-2018)

\begin{tabular}{llllllll}
\hline Representative region & \multicolumn{2}{l}{ Population } & & & \multicolumn{2}{l}{ Morbidity (mean data per year) } \\
\cline { 2 - 3 } & In the city & In the other part of the region & Total & & Allergic rhinitis & Allergic asthma \\
\hline Klaipeda & 149,157 & 216,911 & 366,068 & 444 & 2065 \\
Siauliai & 101,514 & 159,915 & 261,429 & 382 & 1771 \\
Vilnius & 562,030 & 184,822 & 746,852 & 1358 & 4719 \\
\hline
\end{tabular}

pollen season start, end, the SPIn, and peak value during the main pollen season. The package 'epiDisplay' (Chongsuvivatwong, 2018) was used to build quantile-normal plots by integrating Shapiro-Wilk's test results and to test the main pollen season characteristics against the normal distribution. Quantile-normal plots allowed to estimate the scatter of the pollen data.

Processing of the summarised data was performed employing package 'xtable' (Dahl et al., 2019). Due to the relatively small datasets and non-normal distribution, the statistical data analysis was performed using the Mann-Whitney-Wilcoxon rank-sum test. The Mann-Whitney-Wilcoxon test was implemented by comparing pollen data between different aerobiological stations, considering the beginning and end, the SPIn, and peak value of the pollen season. The same test was also selected considering variations of determined pollen load thresholds and comparing the results with pollen thresholds determined in Finland and Poland (de Weger et al., 2013; Jantunen et al., 2012; Rapiejko et al., 2007). Package 'vioplot' was employed to group the determined thresholds of pollen load (Adler, Kelly, 2019). In the graphs, the wider part of the violin plot represents a higher probability, and the thinner part represents a lower probability. In the boxplots, the line indicates the median. Spearman correlation coefficients were calculated for the analysis of allergic rhinitis and allergic asthma morbidity and pollen load data. The $p$-value was calculated with correspondence to a 0.01 and 0.05 probability.

\section{Results}

3.1 Characterisation of the pollen season in Lithuania

Analysing airborne pollen data collected in Lithuania, covering the range of fifteen years (2005-2019), enabled us to characterize pollen behaviour. This study focuses on pollen characteristics that are important for public pollen information. The key points-the dates of the beginning and end of the pollen season (expressed in DOY), peak values (pollen $/ \mathrm{m}^{3}$ ), and the SPIn-are presented in Fig. 3. Results showed that the pollen season start differed in relation to the type of pollen rather than to regionality. Violin plots are similar to box plots as they include a marker for the median of the data and a box or marker indicating the interquartile range. They differ in that they also include a density plot that is rotated and placed on each side, to show how the data are distributed. The width of this plot indicates the frequency of data at a certain level. In the case of Corylus, a trend towards an earlier start of the pollen season in Klaipeda comparing to Vilnius or Siauliai is observed. The concentration of Corylus pollen is the lowest in a group of analysed pollen types. The obvious regional difference in terms of SPIn and peak values are shown in Fig. 3. In contrast, pollen data of Alnus shows no significant geographical differences between the beginning and end of the pollen season. Klaipeda is characterised by higher SPIns and peak values of Alnus pollen than the other stations are.

Comparing with other plant taxa, the start of the Betula pollen season is similar at all monitoring points. However, SPIns are different, and this tendency becomes prominent where high SPIns values are present. There is an obvious regional variation between the three regions regarding herbaceous 

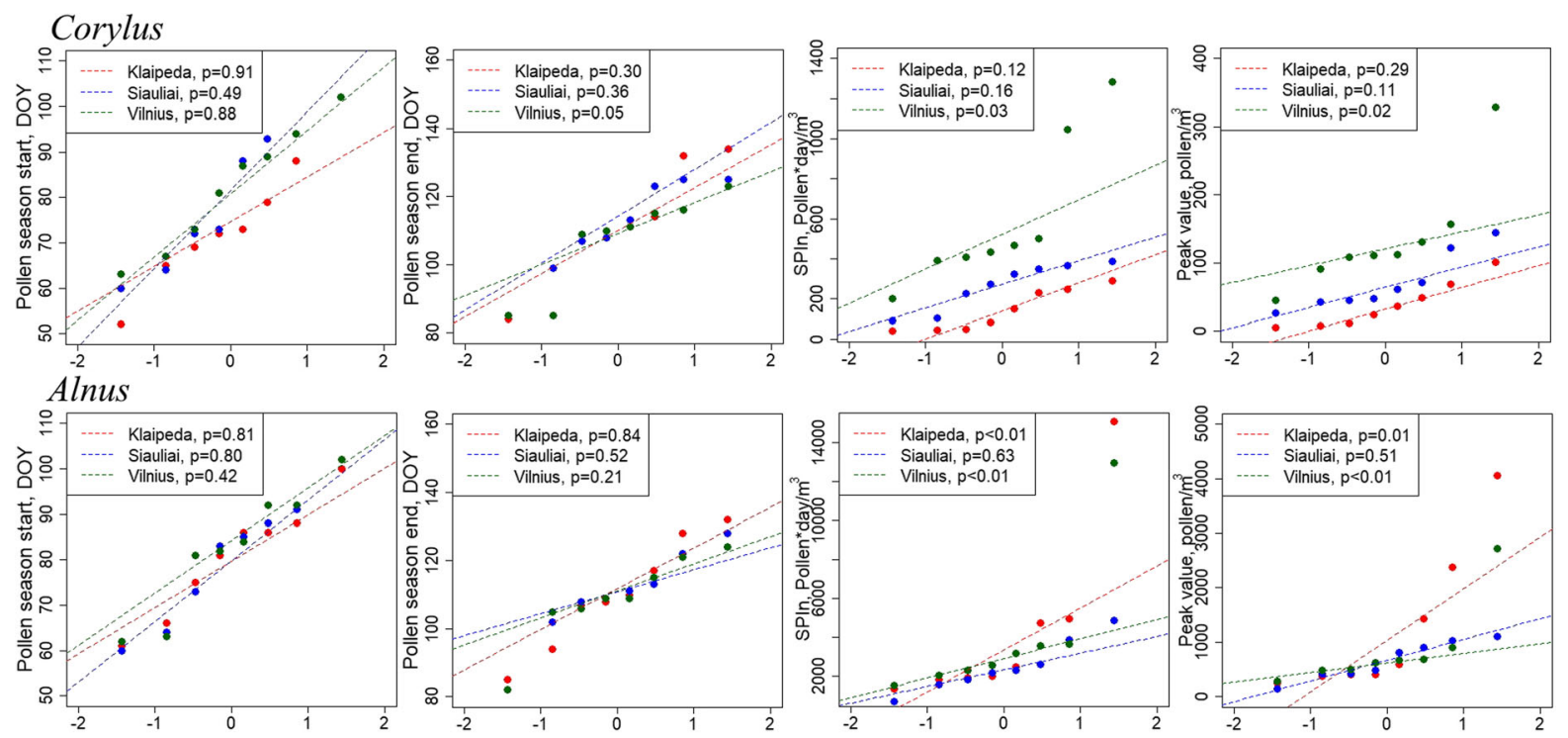

\section{Betula}
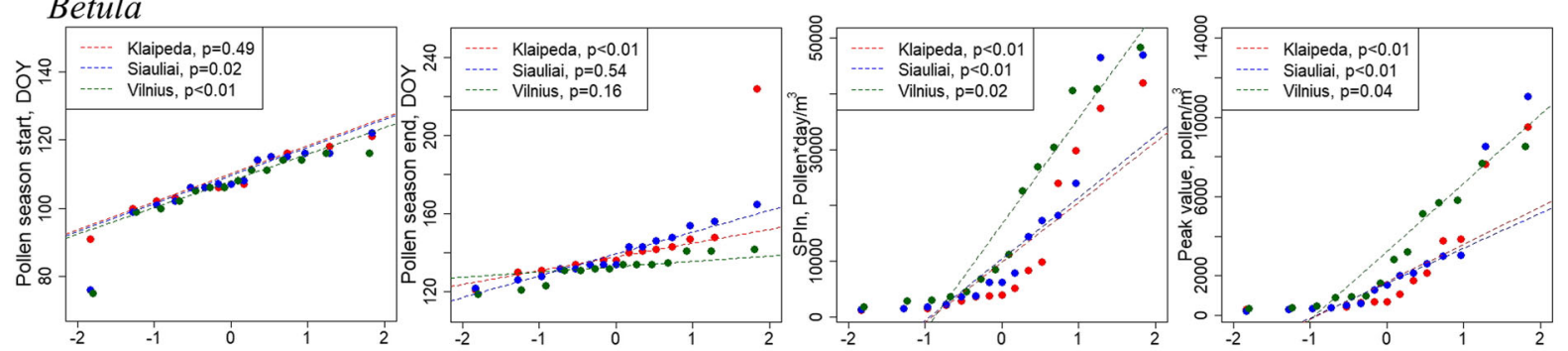

Poaceae
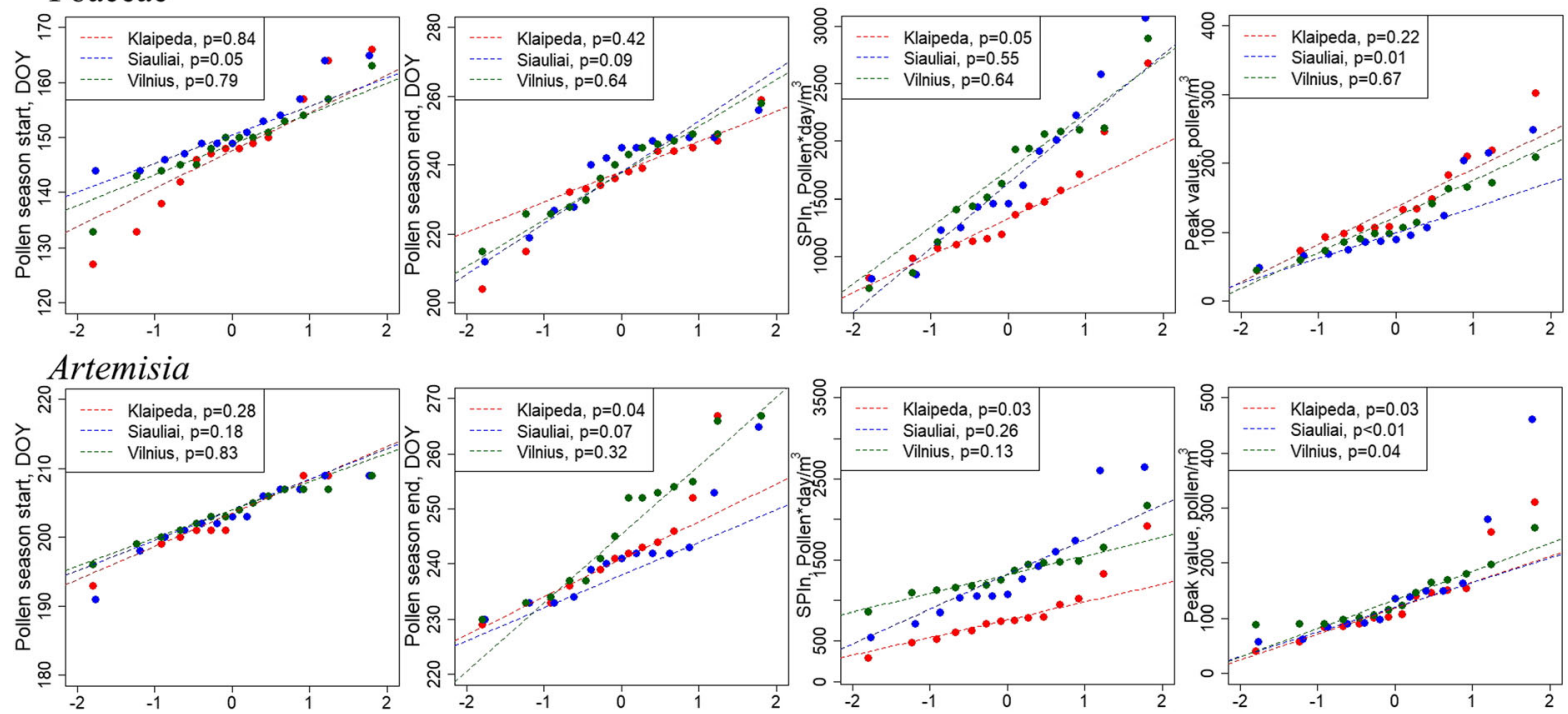

Fig. 3 Airborne pollen season characteristics in Lithuania. Data from 2005 to 2019, with exceptions as noted in the 2.2 Pollen data. The $\mathrm{x}$-axis represents theoretical quantiles (i.e., cut points dividing the range of a probability distribution into continuous

intervals with equal probabilities), and the y-axis, the characteristics of pollen seasons. $p$ indicates the confidence level of ShapiroWilk test (testing for normality) results. Klaipeda, Siauliai, Vilnius-aerobiological stations in Lithuania 
pollen. In Klaipeda, which is on the coast, SPIn is lower than in Siauliai and Vilnius, the mainland of the country. Features of Artemisia pollen concentration had regional differences, i.e., the lowest SPIns are observed in the coastal region. The differences in the start and the end of the pollen season are not as sharp.

Table 3 highlights the key regional tendencies in terms of pollen season dynamics during the study period. Statistically significant differences were identified only for Corylus and Artemisia. In most cases, a difference of 1-5 days in average dates of the pollen season start was found. The start of the Corylus season is on average 7 days earlier only at the aerobiological station located at the seaside comparing to the mainland. The average end of the pollen season is more related to pollen type than regional differences. The territorial trend of the Betula pollen season end showed a 9-day difference comparing Klaipeda and Vilnius cases. In Alnus cases, the differences were detected in the mean values of SPIns. Pollen data collected in Klaipeda featured high concentrations of pollen, which determine the highest SPIn and peak values. The outlining of the results revealed the presence of regional differences in the main pollen season in a relatively small country.

\subsection{Application of different pollen thresholds}

Regional aspects of pollen distribution were associated with determined thresholds of pollen load. The already published threshold levels (Table 1) were used for analysis together with thresholds determined in this study. An experimental comparison provided a possibility to observe the dynamics of the threshold values and to assess the possible applicability of the different thresholds. Thereby we were allowed to compare three groups of pollen thresholds and to review the potential applicability of the determined thresholds. Results are displayed in Fig. 4. A large amount of pollen data fall within the low threshold (Fig. 4), irrespective of the thresholds of which group (TR_FIN, TR_POL, TR_LIT) were applied. TR_FIN and TR_POL for Corylus appear to be too high in relation to the pollen load in Lithuania. The low frequency of thresholds with "high" and "very high" levels was obtained.

Table 3 Comparison of pollen season characteristics in Lithuanian regions, applying the Mann-Whitney-Wilcoxon (W) rank-sum test

\begin{tabular}{|c|c|c|c|c|c|c|c|c|c|c|}
\hline Pollen observation sites & \multicolumn{2}{|c|}{ Corylus } & \multicolumn{2}{|l|}{ Alnus } & \multicolumn{2}{|l|}{ Betula } & \multicolumn{2}{|c|}{ Poaceae } & \multicolumn{2}{|c|}{ Artemisia } \\
\hline \multicolumn{11}{|l|}{ Pollen season start, DOY } \\
\hline Klaipeda/Siauliai & 26.0 & $75 / 81$ & 32.5 & $80 / 80$ & 114.0 & $109 / 107$ & 70.0 & $148 / 152$ & 88.5 & $203 / 203$ \\
\hline Klaipeda/Vilnius & 23.0 & $75 / 82$ & 28.5 & $80 / 82$ & 120.0 & $109 / 106$ & 88.0 & $148 / 149$ & 93.5 & $203 / 204$ \\
\hline Siauliai/Vilnius & 30.5 & $81 / 82$ & 28.5 & $80 / 82$ & 117.5 & $107 / 106$ & 105.0 & $152 / 149$ & 87.5 & $203 / 204$ \\
\hline \multicolumn{11}{|l|}{ Pollen season end, DOY } \\
\hline Klaipeda/Siauliai & 32.0 & $110 / 111$ & 32.0 & $110 / 109$ & 109.5 & $143 / 140$ & 74.0 & $235 / 239$ & 101.0 & $244 / 241$ \\
\hline Klaipeda/Vilnius & 32.0 & $110 / 107$ & 35.0 & $110 / 109$ & 146.0 & $143 / 132$ & 84.0 & $235 / 239$ & 80.5 & $244 / 247$ \\
\hline Siauliai/Vilnius & 35.5 & $111 / 107$ & 33.5 & $109 / 109$ & 143.5 & $140 / 132$ & 100.5 & $239 / 239$ & 67.0 & $241 / 247$ \\
\hline \multicolumn{11}{|l|}{ SPIn } \\
\hline Klaipeda/Siauliai & $12.0^{*}$ & $143 / 265$ & 38.0 & $4304 / 2499$ & 104.0 & $11,805 / 13454$ & 66.0 & $1412 / 1685$ & $36.0 * *$ & $826 / 1354$ \\
\hline Klaipeda/Vilnius & $3.0 * *$ & $143 / 591$ & 28.0 & $4304 / 3988$ & 74.0 & $11,805 / 18016$ & 65.0 & $1412 / 1701$ & $22.0 * *$ & $826 / 1352$ \\
\hline Siauliai/Vilnius & $6.0^{* *}$ & $265 / 591$ & 24.0 & $2499 / 3988$ & 83.0 & $13,454 / 18016$ & 84.0 & $1685 / 1701$ & 72.0 & $1354 / 1352$ \\
\hline \multicolumn{11}{|l|}{ Peak value, pollen $/ \mathrm{m}^{3}$} \\
\hline Klaipeda/Siauliai & 16.0 & $38 / 70$ & 32.0 & $1239 / 664$ & 107.0 & $2232 / 2503$ & 119.5 & $140 / 117$ & 85.5 & $131 / 151$ \\
\hline Klaipeda/Vilnius & $4.0 * *$ & $38 / 135$ & 28.0 & $1239 / 860$ & 76.0 & $2232 / 3178$ & 119.0 & $140 / 116$ & 77.5 & $131 / 139$ \\
\hline Siauliai/Vilnius & $14.0^{*}$ & $70 / 135$ & 30.0 & $664 / 860$ & 85.0 & $2503 / 3178$ & 82.0 & $117 / 116$ & 78.0 & $151 / 139$ \\
\hline
\end{tabular}

Statistical significance denotes a difference between two regions. Statistical reliability of data: $*-\mathrm{p}<0.05, * *-\mathrm{p}<0.01$ 

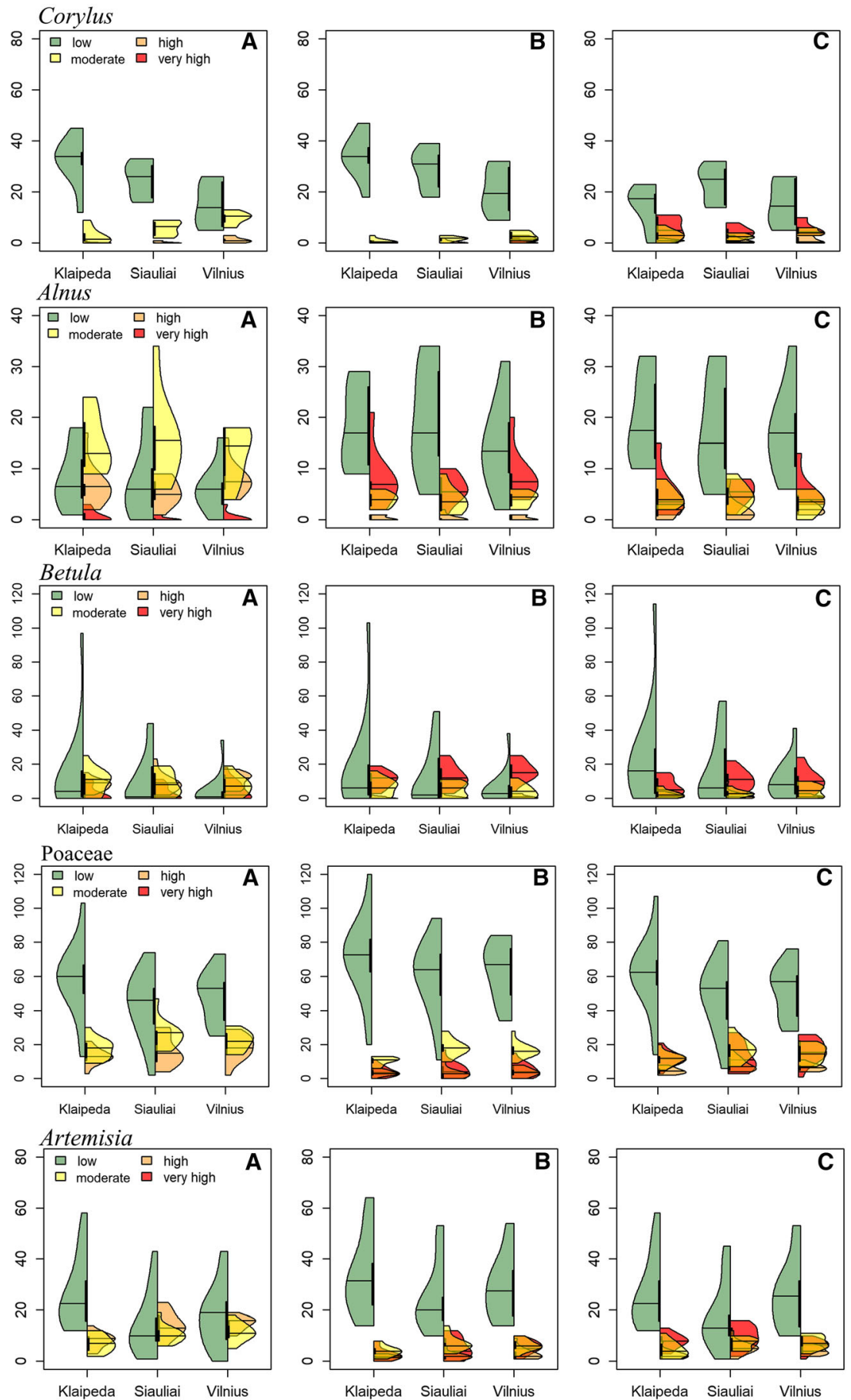

Fig. 4 Frequency of cases (2005-2019) corresponding to pollen load thresholds determined on pollen data of Lithuania and calculated A-TR_FIN, thresholds according to RantioLehtimäki et al., 1991; Jantunen et al., 2012; de Weger et al., 2013; B-TR_POL, thresholds according to Rapiejko et al., 2007; de Weger et al., 2013; C-TR_LIT, thresholds determined by using the $25 \%$ principle, described in this study. $x$-axislocation of the aerobiological station; y-axis-frequency of threshold level. In the violin, the line indicates the median. The density of data is plotted on each side of the vertical axis, which depicts the interquartile range 
The results for Alnus data (Fig. 3, Table 3) which often flowers in parallel to Corylus are different. When TR_FIN thresholds are applied, Alnus pollen data mostly fall into the "moderate" level. In contrast, application of TR_POL thresholds (Fig. 4b Alnus), pollen concentrations often are attributed to the "very high" level. The distribution of TR_LIT threshold values is proportional at the "moderate", "high" and "very high" levels in both Alnus and Betula cases. The TR_FIN threshold for herbaceous plants (Table 1) does not include the "very high" level; therefore, the application of TR_FIN thresholds in the territory of Lithuania is limited. After application of the "very high" level from both TR_POL and TR_LIT thresholds, a more even distribution of Artemisia and Poaceae pollen data is obtained.

The Mann-Whitney-Wilcoxon test (Table 4) was used to compare the results of the three groups' thresholds. The largest and statistically significant ( $p<0.01)$ differences were obtained when comparing the TR_LIT threshold with the TR_FIN. TR_LIT and TR_FIN comparison results show that "moderate" and "high" levels of pollen load differ in principle. TR_LIT threshold results demonstrate that during the pollen season, the pollen load is consistently sitespecific (Fig. 4). The Mann-Whitney-Wilcoxon test reveals that TR_LIT thresholds (determined according to pollen data from Lithuanian aerobiological stations, using the $25 \%$ principle) are relatively similar with TR_POL (determined by pollen concentrations were associated with the health of pollen-sensitive individuals).

A comparative assessment of pollen thresholds has revealed that lowest peak value (used for determining threshold levels) allows defining values that representatively indicate the pollen load. Our study results showed the existence of regional differences between the lowest peak values and, consequently, the defined pollen load thresholds. Considering that the differences between regions are not consistent except for Corylus and Artemisia pollen loads, we formed a representative expression of pollen load for the country. Unified pollen threshold values (Table 5) differ from regional values.

The threshold levels were standardised according to the mean of pollen threshold values but keeping the optimal reflection of the regions. For convenience, unified pollen threshold values could be used for public information purposes.
3.3 Analysis of allergic rhinitis morbidity, pollen season, and thresholds

The set of 2011-2018 data was used for comparison of allergic rhinitis and allergic asthma morbidity with pollen load. During this period, in Lithuania, persons with allergic asthma visited doctors 4 times more often than persons with allergic rhinitis. From the overall visits, about $15 \%$ more males than females were registered. In the age group under 19, about $50 \%$ more males than females were registered considering both types of diseases. In other age groups, the result is inversely proportional.

Figure 5 demonstrates a retrospective analysis of allergic rhinitis and allergic asthma morbidity, showing data of Klaipeda, Siauliai, and Vilnius regions (Fig. 1). The highest morbidity of allergic rhinitis was identified in 2014 for the Klaipeda and the Siauliai regions. This trend is more evident in the groups of age under 19 and of age 20-64. In the Vilnius region, regardless of age group, most cases of allergic rhinitis were recorded in 2018.

The year 2014 is distinguished by high amounts of Betula pollen in all regions, and this corresponds to the abundance of allergic rhinitis and allergic asthma morbidity. High amounts of other pollen types were recorded in 2011, but morbidity of both allergic rhinitis and allergic asthma was relatively low regarding the period of 2011-2018. The high morbidity of allergic rhinitis in Vilnius in 2018 cannot be explained by the high values of selected pollen taxa.

We aimed to analyse the associations between the various pollen threshold groups to recognise the relationship between thresholds and Lithuania's rates of allergic rhinitis and allergic asthma (Table 6). No unambiguous result was identified concerning the threshold association and morbidity data. The highest number of statistically significant associations was found by associating Artemisia pollen load thresholds with morbidity.

Using all three thresholds was identified the same amount of statistically significant cases $(p<0.01$ and $p<0.05$ ). Correlation results reveal that data of allergic asthma presented more statistically significant correlation coefficients than allergic rhinitis data when connected to pollen levels. It should be noted that this tendency came to prominence from any age group over 19 . The number of statistically significant cases was higher ( $>56 \%$ of statistically significant cases) in 
Table 4 Differences in the outcome when different threshold values are applied to pollen data from Lithuania, using the MannWhitney-Wilcoxon ranksum test. TR_FIN: thresholds used in Finland; TR_POL: thresholds used in Poland; TR_LIT: thresholds used in Lithuania.

Statistical reliability of data: $*-\mathrm{p}<0.05, * *-\mathrm{p}<0.01$

Table 5 The unified thresholds of pollen load for Lithuania

\begin{tabular}{|c|c|c|c|c|c|c|c|c|}
\hline \multirow[t]{2}{*}{ Pollen type } & \multicolumn{4}{|c|}{ TR_LIT/TR_FIN } & \multicolumn{4}{|c|}{ TR_LIT/TR_POL } \\
\hline & Low & Medium & High & Very high & Low & Medium & High & Very high \\
\hline \multicolumn{9}{|l|}{ Klaipeda } \\
\hline Corylus & $6.0 * *$ & 36.0 & 52.5 & 60.0 & $4.0 * *$ & 50.0 & 52.5 & 60.0 \\
\hline Alnus & 55.5 & $0.0 * *$ & $4.0 * *$ & 58.0 & 37.5 & 37.0 & 51.5 & $14.0 *$ \\
\hline Betula & 143.5 & $51.0 * *$ & $6.0 * *$ & 178.5 & 135.5 & $67.5^{*}$ & 174.5 & $65.5^{*}$ \\
\hline Poaceae & 116.0 & $42.0 * *$ & $11.0 * *$ & n.a & 64.0 & 119.5 & 137.5 & 181.5 \\
\hline Artemisia & 98.0 & $59.0 *$ & $11.0 * *$ & n.a & 66.5 & 104.0 & 139.0 & 180.5 \\
\hline \multicolumn{9}{|l|}{ Siauliai } \\
\hline Corylus & 24.0 & $11.5^{*}$ & 42.0 & 64.0 & 16.5 & 48.0 & 40.5 & 64.0 \\
\hline Alnus & 50.5 & $3.0 * *$ & $9.5 * *$ & 63.0 & 27.0 & 40.0 & 51.0 & 26.0 \\
\hline Betula & 143.0 & $57.0 *$ & $15.5 * *$ & 191.0 & 134.0 & 83.5 & 136.0 & 90.5 \\
\hline Poaceae & 99.0 & $30.5 * *$ & $31.5 * *$ & n.a & $52.0 *$ & 74.0 & 154.0 & 137.5 \\
\hline Artemisia & 103.5 & $31.5^{* *}$ & $7.5^{* *}$ & n.a & $47.5^{*}$ & 88.5 & 147.0 & 127.0 \\
\hline \multicolumn{9}{|l|}{ Vilnius } \\
\hline Corylus & 35.5 & $3.0 * *$ & 28.0 & 64.0 & 21.0 & 49.5 & 23.5 & 64.0 \\
\hline Alnus & 57.5 & $3.0 * *$ & $0.5 * *$ & 62.5 & 37.5 & 25.5 & 59.5 & $12.0 *$ \\
\hline Betula & 150.0 & 64.0 & $0.0 * *$ & 152.5 & 136.5 & 97.5 & 115.5 & $49.0^{*}$ \\
\hline Poaceae & 117.0 & $32.0 * *$ & $15.0 * *$ & n.a & 56.5 & 80.0 & 157.5 & 179.0 \\
\hline Artemisia & 135.5 & $41.0 * *$ & $0.0 * *$ & n.a & 76.0 & 126.0 & 145.0 & 112.0 \\
\hline
\end{tabular}

\begin{tabular}{lccccc}
\hline Threshold level & \multicolumn{5}{l}{ Threshold values by pollen types } \\
\cline { 2 - 6 } & Corylus & Alnus & Betula & Poaceae & Artemisia \\
\hline Low & $\leq 5$ & $<55$ & $<70$ & $<10$ & $<15$ \\
Moderate & $5-15$ & $55-115$ & $70-150$ & $10-20$ & $15-30$ \\
High & $15-20$ & $115-170$ & $150-215$ & $20-35$ & $30-50$ \\
Very high & $>20$ & $>170$ & $>215$ & $>35$ & $>50$ \\
\hline
\end{tabular}

the groups of the low and moderate pollen levels of TR_LIT threshold comparing with the thresholds of TR_FIN and TR_POL.

Considering the fact that generalised morbidity data does not present the cause of the allergy, a direction of the linear regression trend could be clarified by detailed epidemiological studies in the future.

\section{Discussion}

The study demonstrated regional differences in pollen dispersion in Lithuania. Based on the results about the regional differences, pollen load thresholds were analysed. The estimated data allowed us to compare the thresholds determined for Lithuania with the retrospective morbidity data of three regions. Statistically significant regional differences were found with regard to Corylus and Artemisia pollen load. The variability of seasonal characteristics of other pollen types between stations remains high, especially in the cases of SPIn and peak value. Similar results are found in research performed in other countries, where pollen concentrations are studied at different measurement locations. Differences were confirmed within states (Buters et al., 2015; Pfaar et al., 2019), between individual stations in the same country (Arobba et al., 2000; Camacho et al., 2020; Celenk et al., 2010; Kubik-Komar et al., 2019) or in a particular city (Werchan et al., 2017; Weinberger et al., 2018; Bilinska et al. 2019) as well as pollen recorded in traps installed at different heights (Rantio-Lehtimäki 


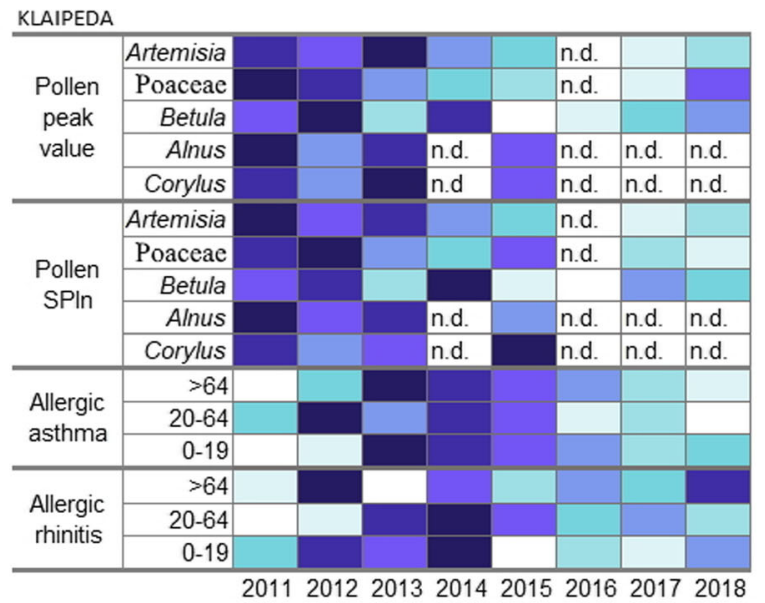

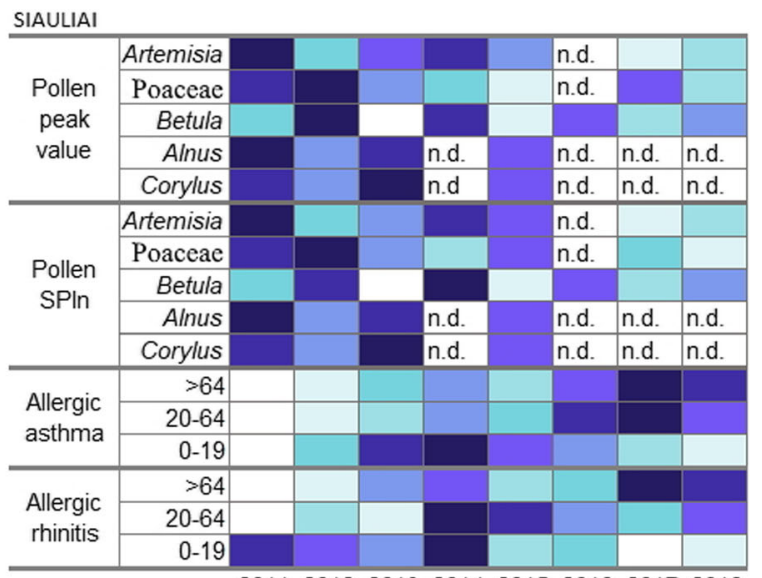

20112012201320142015201620172018

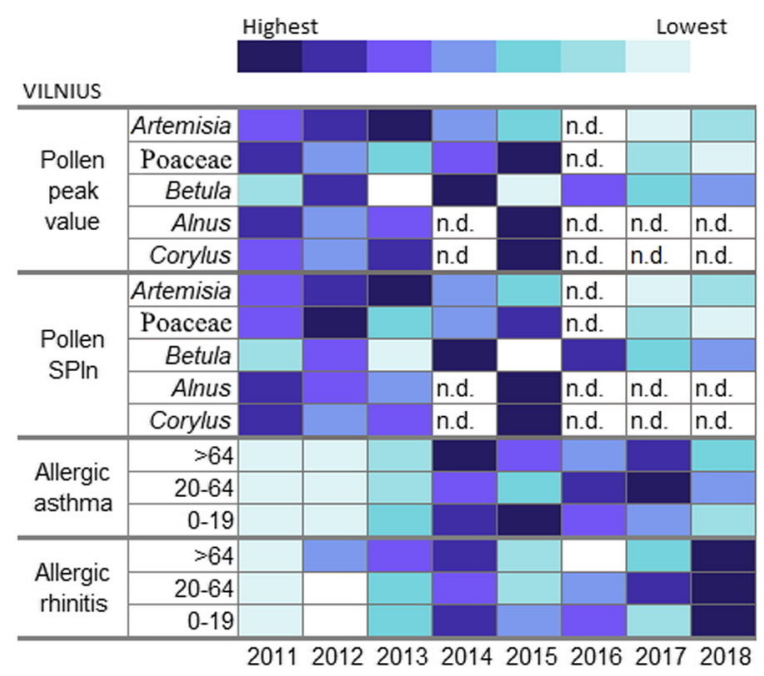

Fig. 5 The retrospective analysis of allergic rhinitis and allergic asthma morbidity in Lithuania regarding the SPIn and pollen peak value. The analysis includes morbidity registered within a radius of $\sim 50 \mathrm{~km}$ from the aerobiological stations. Morbidity

et al., 1991; Rojo et al., 2019). Aforesaid differences are caused not only due to the country's biogeographical peculiarities (Charalampopoulos et al., 2018; Moreno-Grau et al., 2016) but also due to the pollen long-distance transport (Bogawski et al., 2019; Skjøth et al., 2007; Smith et al., 2008; Sofiev et al., 2013; Veriankaite et al., 2010). Pollen trap territorial representability depends on the purpose for which the data will be used. From a perspective of public health, the radius of $30 \mathrm{~km}$ (Katelaris et al., 2004) or $70 \mathrm{~km}$ (Oteros et al., 2019) between traps in the region is defined as acceptable. Although, simultaneously, the effect of canyons formed in urban areas is discussed (Peel et al., 2014). In our study, analysing the cases were grouped by age: $0-19,20-64,>64$. The lowest scores are shown by the lightest blue and the highest scores by the darkest, for the years 2011-2018. n.d.-no pollen data available

tendencies in allergic rhinitis and allergic asthma morbidity in Lithuania, we evaluated the data falling within the $50 \mathrm{~km}$ radius around the aerobiological station (Fig. 1). The representative territory enabled us to incorporate the distribution of airborne pollen and apply study results to regions in Lithuania.

The evaluation of 15-year trends in pollen dispersal in Lithuania has revealed that in the Betulaceae family, which forms the largest SPIn, the main allergenic pollen source plants are Alnus and Betula. This is common for Nordic countries (Linkosalo et al., 2017; Ritenberga et al., 2018). Higher amounts of Corylus pollen are characteristic to Croatia (Peternel et al., 2005), Italy (Rizzi Longo \& Pizzulin Sauli, 


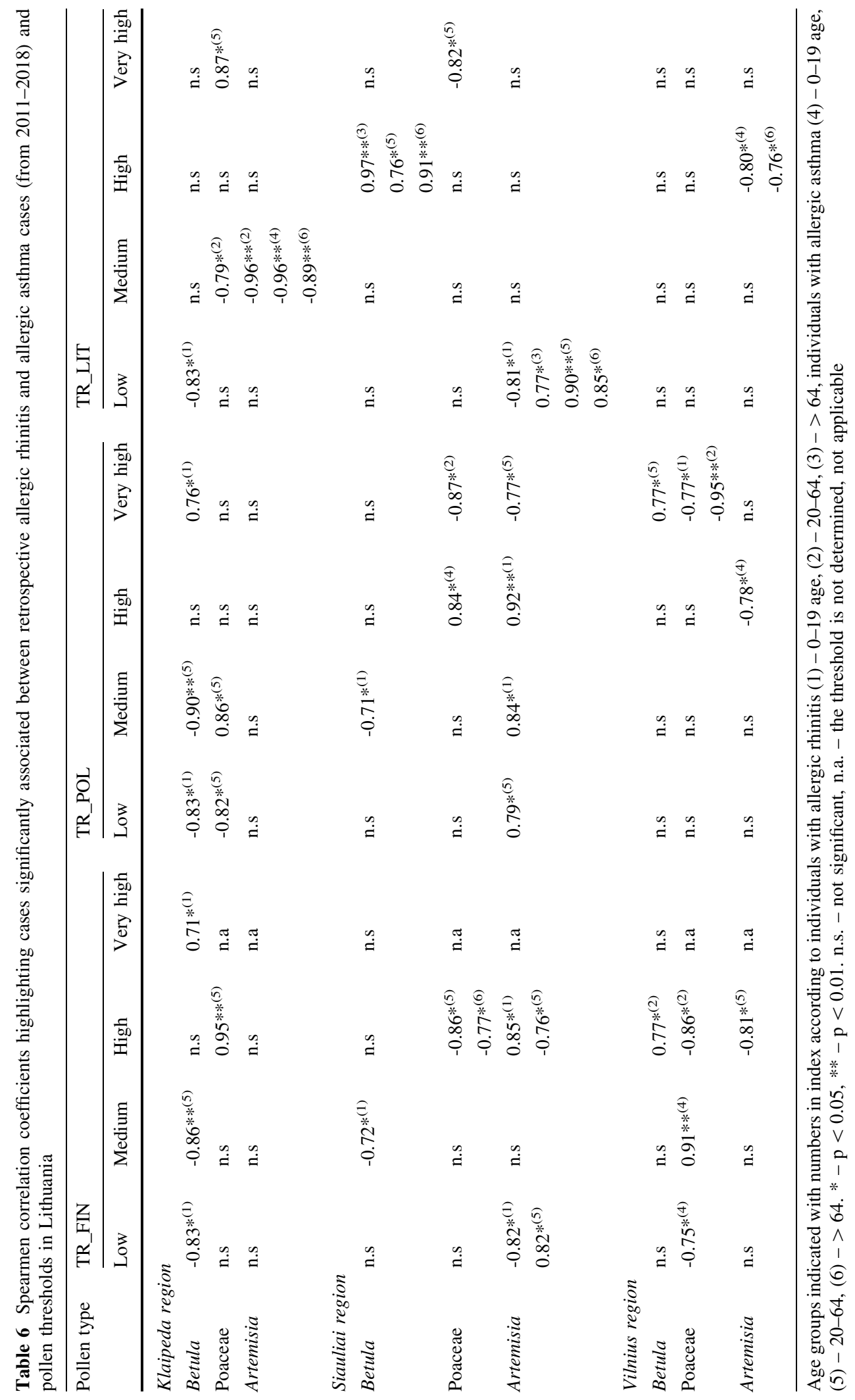


2010), Poland (Puc \& Kasprzyk, 2013), while in Lithuania, more abundant amounts of airborne pollen are recorded at the Vilnius station. In the group of herbaceous plants, an important part of the pollen load consists of Artemisia pollen (Table 3), which is abundant in all regions of the country. According to studies on the manifestation of allergic rhinitis in Lithuania, Artemisia plants have been identified as an important source of allergens (Šaulienè et al., 2015; Staikūnienè et al., 2005).

Exposure to pollen allergens influences the development of allergic rhinitis and allergic asthma (Cingi et al., 2017; Pfaar et al., 2017, 2019). The findings of our research show that the highest Betula SPIn and peak value recorded over 15 years can be associated with the increase in allergic rhinitis and allergic asthma morbidity (Fig. 5). In Europe, plants of this genus are a major cause of spring allergy (WeryszkoChmielewska et al., 2001; Biedermann, 2019). Jantunen et al. (2012) found that almost $90 \%$ of the subjects suffered from allergy symptoms during the peak of Betula pollination. When examining allergic rhinitis morbidity, other spring-flowering plants such as Fraxinus, Quercus, and Carpinus also play an equally important role in results (Guilbert et al., 2016). On the other hand, Poaceae pollen is widely known as significant aeroallergen (García-Mozo, 2017; Pablos et al., 2016), and our research finds in some cases associations between Poaceae pollen load and retrospective morbidity data. When studying the correlation between airborne pollen of various types and individuals with allergies, Cebrino et al. (2017) identified statistically significant correlation coefficients as a result of grass pollen in respect of asthma and allergic rhinitis cases from 2014-2015.

Jantunen et al. (2012) pointed out that associating daily allergy symptoms with a concentration of pollen, results have statistically weak links, although it is crucial to understanding the pollen load thresholds that are applicable for informing on the risks of symptoms becoming more pronounced. Pfaar et al. (2017) provided recommendations on definitions of pollen concentration and exposure times for allergen immunotherapy. Later, continuing research by combining the presented recommendations with the Pollen Diary entries, the authors (Pfaar et al., 2019) characterized birch and grass pollen season start, end, and peak pollen period in all three European regions (Austrian, Finnish, and the French regions), which shows that the territorial uniqueness of thresholds is inevitable. On the other hand, the importance of determining the regional pollen threshold is also indicated by Bastl et al. (2014), who argued that the same amount of pollen provoked different symptom levels in different regions. We have shown in our study that pollen load thresholds can be determined using the lowest peak value of pollen seasons. Until now, no territory-specific pollen thresholds that would help to define pollen load levels have been determined in Lithuania. Using the data of pollen monitoring in Lithuania for 15 years, we compared the thresholds, which applied to the evaluation of pollen load in neighbouring countries. We compared them with the thresholds determined according to pollen data from Lithuanian aerobiological stations (Table 1). The obtained results confirm that the territorial thresholds corresponding to the aerobiological situation are representative and can be used to assess the pollen load in the regions of Lithuania. Considering that the application of scientific knowledge in practice requires more generalised information on pollen load, we proposed derivative thresholds (Table 5), classifying pollen concentration into levels.

\section{Conclusions}

Evaluation of the long-term data on airborne pollen concentrations highlights a trend that the characteristics of the pollen season in the coastal and in the continent regions differ. The regional variations in the main pollen season are related to the parameters of airborne pollen concentration (SPIn and peak value). Statistically significant differences between stations were identified only for Corylus and Artemisia. However, the differences in SPIn and peak value found in the cases of other pollen types are no less important when assessing pollen load in Lithuania.

Based on aerobiological data, the principle enabling to group pollen concentrations of five pollen types into load-defining levels according to the lowest peak value of the pollen season has been analysed. For the first time, pollen load thresholds suitable for the territory of Lithuania have been defined. With this study, we proposed a method to set pollen load thresholds solely on pollen monitoring data. The defined thresholds can be used in epidemiological studies requiring the association with pollen 
concentrations. Levels of pollen thresholds could also complement air quality information by integrating pollen load data into public messages or contribute to the development of mHealth systems.

Acknowledgements This research has received funding from the Research Council of Lithuania (LMTLT), agreement No S-MIP-19-53. The authors are grateful to the Nature Research Center and Klaipeda Seamen's Hospital for the cooperation and the possibility to operate the aerobiological stations.

Author Contribution All the authors made significant contributions to this study. The conceptualization was

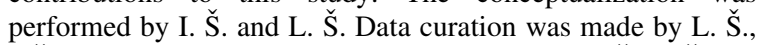

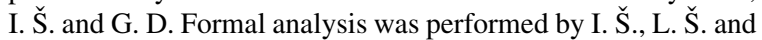
G. D. Investigation was panned and implemented by L. Š., I. Š. and G. D. Supervision was made by O. R. and R. D. Visualization was performed by L. $\breve{S}$ and I. $\breve{S}$. All authors contributed to the writing and editing of the paper.

Funding This research has received funding from the Research Council of Lithuania (LMTLT), agreement No S-MIP-19-53.

\section{Declarations}

Conflict of interest The authors declare that they have no known competing financial interests or personal relationships that could have appeared to influence the work reported in this paper.

Open Access This article is licensed under a Creative Commons Attribution 4.0 International License, which permits use, sharing, adaptation, distribution and reproduction in any medium or format, as long as you give appropriate credit to the original author(s) and the source, provide a link to the Creative Commons licence, and indicate if changes were made. The images or other third party material in this article are included in the article's Creative Commons licence, unless indicated otherwise in a credit line to the material. If material is not included in the article's Creative Commons licence and your intended use is not permitted by statutory regulation or exceeds the permitted use, you will need to obtain permission directly from the copyright holder. To view a copy of this licence, visit http://creativecommons.org/licenses/by/4.0/.

\section{References}

Adler, D., \& Kelly, S. T. (2019). Vioplot: violin plot. R package version 0.3.4. https://github.com/TomKellyGenetics/ vioplot. Accessed 23 March 2020.

Arobba, D., Guido, M. A., Minale, P., Montanari, C., Placereani, S., Pracilio, S., et al. (2000). Airborne pollen in Genoa (NW-Italy): A comparison between two pollen-sampling stations. Aerobiologia, 16, 233-243. https://doi.org/10. 1023/A:1007674620285
Bastl, K., Kmenta, M., Jäger, S., Bergmann, K. C., \& Berger, U. (2014). Development of a symptom load index: Enabling temporal and regional pollen season comparisons and pointing out the need for personalized pollen information. Aerobiologia, 30, 269-280. https://doi.org/10.1007/ s10453-014-9326-6

Bastl, K., Bastl, M., Bergmann, K. C., \& Berger, U. (2019). How to do a clinical trial? Recommendations from the aerobiological point of view. World Allergy Organization Journal, 12, 100020. https://doi.org/10.1016/j.waojou.2019. 100020

Belhassen, M., Demoly, P., Bloch-Morot, E., De Pouvourville, G., Ginoux, M., Chartier, A., et al. (2017). Costs of perennial allergic rhinitis and allergic asthma increase with severity and poor disease control. Allergy, 72, 948-958. https://doi.org/10.1111/all.13098

Biedermann, T., Winther, L., Till, S. J., Panzner, P., Knulst, A., \& Valovirta, E. (2019). Birch pollen allergy in Europe. Allergy, 74, 1237-1248. https://doi.org/10.1111/all.13758

Bilińska, D., Kryza, M., Werner, M., \& Malkiewicz, M. (2019). The variability of pollen concentrations at two stations in the city of Wrocław in Poland. Aerobiologia, 35, 421-439. https://doi.org/10.1007/s10453-019-09567-1

Bogawski, P., Borycka, K., Grewling, Ł, \& Kasprzyk, I. (2019). Detecting distant sources of airborne pollen for Poland: Integrating back-trajectory and dispersion modelling with a satellite-based phenology. Science of the Total Environment, 689, 109-125. https://doi.org/10.1016/j.scitotenv. 2019.06.348

Bonini, M., Gramiccioni, C., Fioretti, D., Ruckert, B., Rinaldi, M., Akdis, C., et al. (2015). Asthma, allergy and the Olympics: A 12-year survey in elite athletes. Current Opinion in Allergy and Clinical Immunology, 15, 184-192. https://doi.org/10.1097/ACI.0000000000000149

Brożek, J. L., Bousquet, J., Agache, I., Agarwal, A., Bachert, C., Bosnic-Anticevich, S., et al. (2017). Allergic rhinitis and its impact on asthma (ARIA) guidelines-2016 revision. Journal of Allergy and Clinical Immunology, 140, 950-958. https://doi.org/10.1016/j.jaci.2017.03.050

Bruffaerts, N., De Smedt, T., Delcloo, A., Simons, K., Hoebeke, L., Verstraeten, C., et al. (2018). Comparative long-term trend analysis of daily weather conditions with daily pollen concentrations in Brussels, Belgium. International Journal of Biometeorology, 62, 483-491. https://doi.org/10.1007/ s00484-017-1457-3

Bukantis, A., Rimkus, E., Gulbinas, Z., Kažys, J., Pupienis, D., Stankūnavičius, G., et al. (2015). Studijos, nustatančios atskiru sektoriụ jautrumą klimato kaitos poveikiui, rizikos vertinimą ir galimybes prisitaikyti prie klimato kaitos, veiksmingiausias prisitaikymo prie klimato kaitos priemones ir vertinimo kriterijus, parengimas. https://am.lrv.lt/ uploads/am/documents/files/Klimato_kaita/jautrumo_ studija.pdf. Accessed 31 March 2020.

Bukantis, A. (2008). Lietuvos klimatas. Visuotine lietuviụ enciklopedija. T. XII: Lietuva https://www.vle.lt/ Straipsnis/Lietuvos-klimatas-117637. Accessed 31 March 2020.

Buters, J., Prank, M., Sofiev, M., Pusch, G., Albertini, R., Annesi-Maesano, I., et al. (2015). Variation of the group 5 grass pollen allergen content of airborne pollen in relation to geographic location and time in season. Journal of 
Allergy and Clinical Immunology, 136, 87-95. https://doi. org/10.1016/j.jaci.2015.01.049

Buters, J. T., Antunes, C., Galveias, A., Bergmann, K. C., Thibaudon, M., Galán, C., et al. (2018). Pollen and spore monitoring in the world. Clinical and Translational Allergy, 8, 9. https://doi.org/10.1186/s13601-018-0197-8

Camacho, I., Caeiro, E., Nunes, C., \& Morais-Almeida, M. (2020). Airborne pollen calendar of Portugal: A 15-year survey (2002-2017). Allergologia Et Immunopathologia, 48, 194-201. https://doi.org/10.1016/j.aller.2019.06.012

Cebrino, J., de la Cruz, S. P., Barasona, M. J., Alcázar, P., Moreno, C., Domínguez-Vilches, E., et al. (2017). Airborne pollen in Córdoba City (Spain) and its implications for pollen allergy. Aerobiologia, 33, 281-291. https://doi. org/10.1007/s10453-016-9469-8

Celenk, S., Bicakci, A., Tamay, Z., Guler, N., Altunoglu, M. K., Canitez, Y., et al. (2010). Airborne pollen in European and Asian parts of Istanbul. Environmental Monitoring and Assessment, 164, 391-402. https://doi.org/10.1007/ s10661-009-0901-1

Charalampopoulos, A., Lazarina, M., Tsiripidis, I., \& Vokou, D. (2018). Quantifying the relationship between airborne pollen and vegetation in the urban environment. Aerobiologia, 34, 285-300. https://doi.org/10.1007/s10453-0189513-y

Chongsuvivatwong, V. (2018). epiDisplay: Epidemiological Data Display Package, 2015. R package version, 3(2.0). https://cran.r-project.org/web/packages/epiDisplay/ epiDisplay.pdf. Accessed 02 March 2020.

Cingi, C., Gevaert, P., Mösges, R., Rondon, C., Hox, V., Rudenko, M., et al. (2017). Multi-morbidities of allergic rhinitis in adults: European academy of allergy and clinical immunology task force report. Clinical and Translational Allergy, 7, 17. https://doi.org/10.1186/s13601-017-0153-z

Dahl, D. B., Scott, D., Roosen, C., Magnusson, A., Swinton, J., Shah, A., et al. (2019). Package 'xtable'. https://cran.rproject.org/web/packages/xtable/xtable.pdf. Accessed 02 March 2020.

Damialis, A., Häring, F., Gökkaya, M., Rauer, D., Reiger, M., Bezold, S., et al. (2019). Human exposure to airborne pollen and relationships with symptoms and immune responses: Indoors versus outdoors, circadian patterns and meteorological effects in alpine and urban environments. Science of the Total Environment, 653, 190-199. https:// doi.org/10.1016/j.scitotenv.2018.10.366

de Weger, L. A., Bergmann, K. C., Rantio-Lehtimäki, A., Dahl, A., Buters, J., Déchamp, C., et al. (2013). Impact of pollen. In M. Sofiev \& K. C. Bergmann (Eds.), Allergenic Pollen (pp. 161-215). Springer.

Galán, C., Smith, M., Thibaudon, M., Frenguelli, G., Oteros, J., Gehrig, R., et al. (2014). Pollen monitoring: Minimum requirements and reproducibility of analysis. Aerobiologia, 30, 385-395. https://doi.org/10.1007/s10453-014-9335-5

Galán, C., Ariatti, A., Bonini, M., Clot, B., Crouzy, B., Dahl, A., et al. (2017). Recommended terminology for aerobiological studies. Aerobiologia, 33, 293-295. https://doi.org/10. 1007/s10453-017-9496-0

García-Mozo, H. (2017). Poaceae pollen as the leading aeroallergen worldwide: A review. Allergy, 72, 1849-1858. https://doi.org/10.1111/all.13210
Goldberg, C., Buch, H., Moseholm, L., \& Weeke, E. V. (1988). Airborne pollen records in Denmark, 1977-1986. Grana, 27, 209-217.

Guilbert, A., Simons, K., Hoebeke, L., Packeu, A., Hendrickx, M., De Cremer, K., et al. (2016). Short-term effect of pollen and spore exposure on allergy morbidity in the Brussels-capital region. EcoHealth, 13, 303-315. https:// doi.org/10.1007/s10393-016-1124-x

Hirst, J. (1952). An automatic volumetric spore trap. Annals of Applied Biology, 39, 257-265. https://doi.org/10.1111/j. 1744-7348.1952.tb00904.x

Jantunen, J., Saarinen, K., \& Rantio-Lehtimäki, A. (2012). Allergy symptoms in relation to alder and birch pollen concentrations in Finland. Aerobiologia, 28, 169-176. https://doi.org/10.1007/s10453-011-9221-3

Jochner, S., Lüpke, M., Laube, J., Weichenmeier, I., Pusch, G., Traidl-Hoffmann, C., et al. (2015). Seasonal variation of birch and grass pollen loads and allergen release at two sites in the German Alps. Atmospheric Environment, 122, 83-93. https://doi.org/10.1016/j.atmosenv.2015.08.031

Jõgiste, K., Korjus, H., Stanturf, J. A., Frelich, L. E., Baders, E., Donis, J., et al. (2017). Hemiboreal forest: Natural disturbances and the importance of ecosystem legacies to management. Ecosphere, 8, e01706. https://doi.org/10.1002/ ecs2.1706

Katelaris, C. H., Carrozzi, F. M., Burke, T. V., \& Byth, K. (2000). A springtime Olympics demands special consideration for allergic athletes. Journal of Allergy and Clinical Immunology, 106, 260-266. https://doi.org/10.1067/mai. 2000.108603

Katelaris, C. H., Burke, T. V., \& Byth, K. (2004). Spatial variability in the pollen count in Sydney, Australia: Can one sampling site accurately reflect the pollen count for a region? Annals of Allergy, Asthma \& Immunology, 93, 131-136. https://doi.org/10.1016/S1081-1206(10)61464-0

Kubik-Komar, A., Piotrowska-Weryszko, K., Weryszko-Chmielewska, E., Kuna-Broniowska, I., Chłopek, K., Myszkowska, D., et al. (2019). A study on the spatial and temporal variability in airborne Betula pollen concentration in five cities in Poland using multivariate analyses. Science of the Total Environment, 660, 1070-1078. https:// doi.org/10.1016/j.scitotenv.2019.01.098

Lahiri, K. R., Tullu, M. S., \& Kalra, R. (2010). Clinical profile, co-morbidities and health related quality of life in pediatric patients with allergic rhinitis and Asthma. Al Ameen Journal of Medical Sciences, 3, 300-311.

Linkosalo, T., Le Tortorec, E., Prank, M., Pessi, A. M., \& Saarto, A. (2017). Alder pollen in Finland ripens after a short exposure to warm days in early spring, showing biennial variation in the onset of pollen ripening. Agricultural and Forest Meteorology, 247, 408-413. https:// doi.org/10.1016/j.agrformet.2017.08.030

Lithuania Statistics (2020). Geographical data. https://osp.stat. gov.lt/geografiniai-duomenys1. Accessed 24 March 2020.

Lithuanian Hydrometeorological service (LHMS) (2020). Klimato rajonavimas. http://www.meteo.lt/lt/klimatorajonavimas. Accessed 25 March 2020.

Marchetti, P., Pesce, G., Villani, S., Antonicelli, L., Ariano, R., Attena, F., et al. (2017). Pollen concentrations and prevalence of asthma and allergic rhinitis in Italy: Evidence from 
the GEIRD study. Science of the Total Environment, 584, 1093-1099.

Matricardi, P. M., Dramburg, S., Alvarez-Perea, A., AntolínAmérigo, D., Apfelbacher, C., Atanaskovic-Markovic, M., et al. (2020). The role of mobile health technologies in allergy care: An EAACI position paper. Allergy, 75, 259-272. https://doi.org/10.1016/j.scitotenv.2017.01.168

Moreno-Grau, S., Aira, M. J., Elvira-Rendueles, B., FernándezGonzález, M., Fernández-González, D., García-Sánchez, A., et al. (2016). Assessment of the Olea pollen and its major allergen Ole e 1 concentrations in the bioearosol of two biogeographical areas. Atmospheric Environment, 145, 264-271. https://doi.org/10.1016/j.atmosenv.2016.09.040

Oduber, F., Calvo, A. I., Blanco-Alegre, C., Castro, A., VegaMaray, A. M., Valencia-Barrera, R. M., et al. (2019). Links between recent trends in airborne pollen concentration, meteorological parameters and air pollutants. Agricultural and Forest Meteorology, 264, 16-26. https://doi.org/10. 1016/j.agrformet.2018.09.023

Oteros, J., Sofiev, M., Smith, M., Clot, B., Damialis, A., Prank, M., et al. (2019). Building an automatic pollen monitoring network (ePIN): Selection of optimal sites by clustering pollen stations. Science of the Total Environment, 688, 1263-1274. https://doi.org/10.1016/j.scitotenv.2019.06. 131

Pablos, I., Wildner, S., Asam, C., Wallner, M., \& Gadermaier, G. (2016). Pollen allergens for molecular diagnosis. Current Allergy and Asthma Reports, 16, 31. https://doi.org/10. 1007/s11882-016-0603-z

Peel, R. G., Kennedy, R., Smith, M., \& Hertel, O. (2014). Do urban canyons influence street level grass pollen concentrations? International Journal of Biometeorology, 58, 1317-1325. https://doi.org/10.1007/s00484-013-0728-x

Peternel, R., Srnec, L., Hrga, I., Hercog, P., \& Čulig, J. (2005). Airborne pollen of Betula, Corylus and Alnus in Zagreb croatia a three-year record. Grana, 44, 187-191. https:// doi.org/10.1080/00173130500188772

Pfaar, O., Bastl, K., Berger, U., Buters, J., Calderon, M. A., Clot, B., et al. (2017). Defining pollen exposure times for clinical trials of allergen immunotherapy for pollen-induced rhinoconjunctivitis-an EAACI position paper. Allergy, 72, 713-722. https://doi.org/10.1111/all.13092

Pfaar, O., Karatzas, K., Bastl, K., Berger, U., Buters, J., Darsow, U., et al. (2019). Pollen season is reflected on symptom load for grass and birch pollen-induced allergic rhinitis in different geographic areas-an EAACI task force report. Allergy. https://doi.org/10.1111/all.14111

Puc, M., \& Kasprzyk, I. (2013). The patterns of Corylus and Alnus pollen seasons and pollination periods in two Polish cities located in different climatic regions. Aerobiologia, 29, 495-511. https://doi.org/10.1007/s10453-013-9299-x

R Core Team (2018). R: A Language and Environment for Statistical Computing. R Foundation for Statistical Computing. https://www.R-project.org/. Accessed 03 February 2020.

R Studio Team (2016). R Studio: Integrated Development for R. R Studio. http://www.rstudio.com/. Accessed 03 February 2020.

Rahman, A., Luo, C., Khan, M. H. R., Ke, J., Thilakanayaka, V., \& Kumar, S. (2019). Influence of atmospheric PM2. 5, $\mathrm{PM} 10, \mathrm{O} 3, \mathrm{CO}, \mathrm{NO} 2, \mathrm{SO} 2$, and meteorological factors on the concentration of airborne pollen in Guangzhou China. Atmospheric Environment, 212, 290-304. https://doi.org/ 10.1016/j.atmosenv.2019.05.049

Rantio-Lehtimäki, A., Koivikko, A., Kupias, R., Mäkinen, Y., \& Pohjola, A. (1991). Significance of sampling height of airborne particles for aerobiological information. Allergy, 46, 68-76. https://doi.org/10.1111/j.1398-9995.1991. tb00545.x

Rapiejko, P., Stanlaewicz, W., Szczygielski, K., \& Jurkiewicz, D. (2007). Threshold pollen count necessary to evoke allergic symptoms. Polish Journal of Otolaryngology, 61, 591-594. https://doi.org/10.1016/S0030-6657(07)70491-2

Ritenberga, O., Sofiev, M., Siljamo, P., Saarto, A., Dahl, A., Ekebom, A., et al. (2018). A statistical model for predicting the inter-annual variability of birch pollen abundance in Northern and North-Eastern Europe. Science of the Total Environment, 615, 228-239. https://doi.org/10.1016/j. scitotenv.2017.09.061

Rizzi Longo, L., \& Pizzulin Sauli, M. (2010). Flowering phenology and airborne pollen occurrence of Corylus and Castanea in Trieste (Italy), 1991-2004. Acta Botanica Croatica, 69, 199-162.

Rojo, J., Oteros, J., Pérez-Badi, R., Cervigón, P., Ferencova, Z., Gutiérrez-Bustillo, A. M., et al. (2019). Near-ground effect of height on pollen exposure. Environmental Research, 174, 160-169. https://doi.org/10.1016/j.envres.2019.04. 027

Šauliene, I., Greičiuvienė, J., Šukienè, L., Juškevičiute, N., Benner, C., Zinkevičienè, A., et al. (2015). Genetic loci associated with allergic sensitization in Lithuanians. PLoS ONE, 10, e0134188. https://doi.org/10.1371/journal.pone. 0134188

Sauliene, I., Sukiene, L., \& Kazlauskiene, V. (2019). The assessment of atmospheric conditions and constituents on allergenic pollen loads in Lithuania. Journal of Environmental Management, 250, 109469. https://doi.org/10.1016/ j.jenvman.2019.109469

Skjøth, C. A., Sommer, J., Stach, A., Smith, M., \& Brandt, J. (2007). The long-range transport of birch (Betula) pollen from Poland and Germany causes significant pre-season concentrations in Denmark. Clinical \& Experimental Allergy, 37, 1204-1212. https://doi.org/10.1111/j.13652222.2007.02771.x

Smith, M., Skjøth, C. A., Myszkowska, D., Uruska, A., Puc, M., Stach, A., et al. (2008). Long-range transport of Ambrosia pollen to Poland. Agricultural and Forest Meteorology, 148, 1402-1411. https://doi.org/10.1016/j.agrformet.2008. 04.005

Sofiev, M., Belmonte, J., Gehrig, R., Izquierdo, R., Smith, M., Dahl, A., et al. (2013). Airborne pollen transport. In: Sofiev M., Bergmann K. C. (Eds.), Allergenic Pollen (pp. 127-159). Dordrecht: Springer. https://doi.org/10.1007/ 978-94-007-4881-1_5.

Stagelund, S., Andersen, K. G., Søe, J., Roslind, M., \& Wildgaard, K. (2019). Use of medication at the roskilde (Denmark) music festival 2015-A prospective observational study of 15,133 treated attendees. Prehospital and Disaster Medicine, 34, 407-414. https://doi.org/10.1017/ S1049023X19004606 
Staikūnienè, J., Japertienė, L. M., \& Sakalauskas, R. (2005). Žiedadulkiụ ir maisto alergenais įsijautrinimo itaka polinozès klinikiniams požymiams. Medicina, 41, 208-216.

State Forest Service (2019). Lithuanian Statistical Yearbook of Forestry 2018. Vilnius, Lithuania. https://osp.stat.gov.lt/ services-portlet/pub-edition-file?id=34180. Accessed 03 March 2020.

Statistics Lithuania (2020). Number of population in Klaipeda, Šiauliai and Vilnius region https://osp.stat.gov.lt/en. Accessed 13 March 2020.

Tesendic, D., Boberic Krsticev, D., Matavlulj, P., Brdar, S., Panic, M., Minic, V., \& Sikoparija, B. (2020). RealForAll: Real-time system for automatic detection of airborne pollen. Enterprise Information Systems. https://doi.org/10. 1080/17517575.2020.1793391

Thibaudon, M. (2003). The allergy risk associated with pollens in France. European Annals of Allergy and Clinical Immunology, 35, 170-172.

Valiulis, A., Bousquet, J., Veryga, A., Suprun, U., Sergeenko, D., Cebotari, S., et al. (2019). Vilnius Declaration on chronic respiratory diseases: Multisectoral care pathways embedding guided self-management, mHealth and air pollution in chronic respiratory diseases. Clinical and
Translational Allergy, 9, 7. https://doi.org/10.1186/ s13601-019-0242-2

Veriankaite, L., Siljamo, P., Sofiev, M., Šaulienè, I., \& Kukkonen, J. (2010). Modelling analysis of source regions of long-range transported birch pollen that influences allergenic seasons in Lithuania. Aerobiologia, 26, 47-62. https://doi.org/10.1007/s10453-009-9142-6

Weinberger, K. R., Kinney, P. L., Robinson, G. S., Sheehan, D., Kheirbek, I., Matte, T. D., et al. (2018). Levels and determinants of tree pollen in New York City. Journal of Exposure Science \& Environmental Epidemiology, 28, 119-124. https://doi.org/10.1038/jes.2016.72

Werchan, B., Werchan, M., Mücke, H. G., Gauger, U., Simoleit, A., Zuberbier, T., et al. (2017). Spatial distribution of allergenic pollen through a large metropolitan area. Environmental Monitoring and Assessment, 189, 169. https:// doi.org/10.1007/s10661-017-5876-8

Weryszko-Chmielewska, E., Puc, M., \& Rapiejko, P. (2001). Comparative analysis of pollen counts of Corylus, Alnus and Betula in Szczecin, Warsaw and Lublin (2000-2001). Annals of Agricultural and Environmental Medicine, 8, 235. 